\title{
Changes in the volatile profile of Brassica oleracea due to feeding and oviposition by Murgantia histrionica (Heteroptera: Pentatomidae)
}

\author{
Eric CONTI ${ }^{1}$, Claudia ZADRA ${ }^{2}$, Gianandrea SALERNO ${ }^{1}$, Benedetta LEOMBRUni $^{1}$, Daniela VOLPE ${ }^{2}$, \\ FRANCESCA FRATI ${ }^{1}$, CESARE MARUCCHINI ${ }^{2}$ and FERDINANDO BIN ${ }^{1}$
}

Department of Agricultural and Environmental Sciences - Entomology ${ }^{1}-$ Chemistry $^{2}$; University of Perugia, Borgo XX Giugno 74, 06121 Perugia, Italy; e-mail: econti@unipg.it

Key words. Heteroptera, Pentatomidae, Murgantia histrionica, herbivore-induced plant volatiles, feeding, oviposition, Brassicaceae

\begin{abstract}
The mixture of volatile compounds emitted by Brassica oleracea var. sabauda changed significantly in response to feeding and/or oviposition by Murgantia histrionica (Heteroptera: Pentatomidae). Volatiles were collected from (1) healthy plants and those with (2) feeding punctures, (3) a combination of feeding punctures and oviposition, (4) feeding punctures and one hatched egg mass and (5) plants bearing only an egg mass. In the case of plants with feeding punctures or feeding punctures plus an egg mass, the volatiles were also collected at different time intervals after plants were subjected to these two treatments $(0-24 \mathrm{~h}, 24-48 \mathrm{~h}$ and 48-72 h). Gas chromatographic and gas chromatograph-mass spectrometric analysis showed that the percent emission of several compounds changed significantly from plants subjected to the feeding and oviposition or just oviposition. Percentage of terpenes generally decreased after feeding and oviposition, although the percentage emission of $(E)$ - $\beta$-caryophyllene from these plants and those with just feeding punctures significantly increased. Plants with just an egg mass emitted linalool de novo but not $(E)-\beta-$ ocimene. The emission of jasmonates, mainly methyl jasmonate, increased from plants with feeding punctures plus an egg mass compared to those with only an egg mass. Higher percentages of the volatile glucosinolate derivatives (VGSs), mainly 4-methoxy-3indolylacetonitrile, were emitted by plants with feeding punctures and an egg mass. The percentage emission of most of these compounds increased during the first $24 \mathrm{~h}$ after the treatment and then decreased over the next $24 \mathrm{~h}$, except for methyl jasmonate, which remained high also $48-72 \mathrm{~h}$ later. The possible ecological roles of such volatiles in plant interactions with the second and third trophic levels are discussed.
\end{abstract}

\section{INTRODUCTION}

Chemical changes in plants damaged by insects have interested plant physiologists and ecologists, ever since these changes were considered to function as possible defences against herbivores (Green \& Ryan, 1972). In particular, the studies on plants' volatile organic compounds (VOCs) provide useful information on plant interactions with other organisms, their physiological status and the level of stress they are experiencing. Plants are known to release more than 30,000 different VOCs including alkanes, alkenes, alcohols, ketones, aldehydes, ethers, esters and carboxylic acids (Niinemets et al., 2004). The most important emitted VOCs can be categorized into three basic chemical classes according to their biosynthetic pathways: the fatty acid-derivatives [green leaf volatiles (GLV) and jasmonates] produced by the lipoxygenase pathway, the terpenoids by the isoprenoid pathway (via mevalonate or deoxyxylulose) and aromatic compounds, such as methyl salicylate and indole, by the shikimic acid pathway.

Many VOCs are constitutively emitted by undamaged plants, but biotic factors and the interaction between biotic and abiotic factors can induce plants to emit much larger amounts of these compounds (Gouinguené \& Turlings, 2002) and may also trigger the de novo synthesis of several VOCs (Paré \& Tumlinson, 1997a, b). In particular, the induction and release of such compounds depends on the interaction of biotic factors, such as hor- mones (de Bruxelles \& Roberts, 2001; Thaler et al., 2002; Farmer et al., 2003; Rojo et al., 2003; Ament et al., 2004; van Poecke \& Dicke, 2004), herbivore-derived elicitors (Alborn et al., 1997; Halitschke et al., 2001; Schmelz et al., 2001; Arimura et al., 2005) and associated microorganisms (Cardoza et al., 2002), and on abiotic factors, such as mechanical wounding (Schmelz et al., 2001; Mithöfer et al., 2005), $\mathrm{O}_{3}$ and $\mathrm{CO}_{2}$ concentration (Vuorinen et al., 2004a, b), UV radiation (Johnson et al., 1999; Winter \& Rostás, 2008), heavy metals (Mithöfer et al., 2004), temperature (Gouinguené \& Turlings, 2002) and light (Takabayashi et al., 1994; Gouinguené \& Turlings, 2002).

VOCs emitted as a consequence of herbivore attack may have a role in plant indirect defences, attracting natural enemies of herbivores and helping them to find the attacked plants (induced synomones) (Dicke \& Sabelis 1988; Turlings et al., 1990; Agrawal et al., 1999; Walling, 2000). These compounds are recorded for more than 15 different tritrophic systems, suggesting that herbivore induced synomones are a common phenomenon, with possible applications in biological control programs (Cortesero et al., 2000; Degenhardt et al., 2003).

Previous research has focused mainly on synomones induced by insects that damage plants by chewing, such as caterpillars (Potting et al., 1995; De Moraes et al., 1998), or mites that feed on cell contents (Takabayashi \& Dicke, 1996). Leaf-eating by caterpillars activate plant 
defence by means of chemical elicitors present in their oral secretions and regurgitants (Alborn et al., 1997, Arimura et al., 2005). Recently there has been an increase in the information on tritrophic systems comprising herbivores with phloem-feeding or stylet-sheath-feeding habits, such as Homoptera and Heteroptera (Bernasconi et al., 1998; Du et al., 1998; Turlings et al., 1998b; Guerrieri et al., 1999; Rodriguez-Saona et al., 2002). These feeding habits generally are characterized by limited mechanical damage and may elicit somewhat different responses from those activated by defoliators (Walling, 2000).

Furthermore, synomones, acting over long (volatile) or very short range (volatile or through contact), are induced not only by feeding but also by oviposition by herbivores, although so far this has been shown for only a few tritrophic systems (Meiners \& Hilker, 2000; Hilker \& Meiners, 2002, 2006; Hilker et al., 2002; Colazza et al., 2004a, b; Conti et al., 2006). As reported by Colazza and coauthors (2004a) bean plants react to feeding and oviposition by Nezara viridula L. (Heteroptera: Pentatomidae) by changing the profile of volatiles emitted, thus attracting the egg parasitoid Trissolcus basalis (Hymenoptera: Scelionidae).

Some VOCs are taxon specific whereas others appear to be common to many different plant families. For example the glucosinolates (GSs) are secondary metabolites typical of brassicaceous crops (Halkier \& Liangcheng, 1997; Walling, 2000; Mattiacci et al., 2001a ). GSs are implicated in plant defence against various insects and pathogens, and they are important in hostplant recognition by specialized predators (Mattiacci et al., 2001a; Bukovinszky et al., 2005). The biologically active molecules are not the intact GSs but the hydrolysis products that are formed and released into the environment only when tissue is damaged. The levels of such products (i.e. isothiocyanates) can be increased in Brassica napus by wounding (Bodnaryk, 1994), insect feeding (Hopkins et al., 1998), treatment with hormones like methyl jasmonate (MeJa) or jasmonic acid (Bodnaryk, 1994; Doughty et al., 1995) and also by fungal infection (Doughty et al., 1991). Herbivore attack, particularly by chewing insects, causes tissue disruption, thereby bringing GSs into contact with myrosinase, which results in the production of a variety of toxic degradation compounds. The role of the GSs myrosinase system in plant interactions with insect herbivores was recently reviewed (Agrawal \& Kurashige, 2003; Renwick et al., 2006).

In this paper we present the results of investigations on the induced VOCs emitted by Brassica oleracea L. (var. sabauda) plants attacked by the harlequin bug Murgantia histrionica Hahn (Heteroptera: Pentatomidae), a pest of cabbage and other brassicaceous crops (McPherson, 1982). We show that cabbage plants with feeding punctures and/or an egg mass deposited by $M$. histrionica change their volatile blend and that the emission of some compounds varies in time. These results provide information for studies necessary on tri-trophic interactions involving egg parasitoids (Colazza et al., 2004b; Conti et al., 2006).

\section{MATERIAL AND METHODS}

\section{Insects}

Murgantia histrionica, originated from individuals collected from cabbage in the Beltsville area, Maryland, was reared in quarantine conditions in a climate room $\left(25 \pm 1^{\circ} \mathrm{C}, 60 \pm 5 \% \mathrm{RH}\right.$, $16 \mathrm{~L}: 8 \mathrm{D})$ inside plastic cages $(30 \times 19.5 \times 12.5 \mathrm{~cm})$ with $5 \mathrm{~cm}$ diameter mesh-covered holes. All stages were fed leaves of cabbage and broccoli. The food was replaced three times per week, and egg masses transferred to other cages for nymphal development.

\section{Plants}

Seeds of Brassica oleracea var. sabauda (cv. Salto, kindly provided by Royal Sluis Brand) were individually planted in pots filled with peat and after $\sim 7$ days were transplanted into plastic pots filled with a mixture of inert substrates such as agriperlite (BPB Vic; Agrimport, Italy) and vermiculite. Plants were kept in a greenhouse under controlled conditions $(25 \pm$ $1{ }^{\circ} \mathrm{C}, 12 \mathrm{~L}: 12 \mathrm{D}$ and $\left.50-60 \% \mathrm{RH}\right)$, watered daily and fertilized with a water solution of Flory 9 Hydro (N-P-K 15-7-22) (Planta Regenstauf, distributed from Agrimport S.p.A.), sequestrene (NK 3-15 containing Fe EDDHA, produced by Syngenta) and urea (produced by Hydro Agri Italia Milano) (1 1 solution: $1 \mathrm{~g}$ Flory 9, $0.04 \mathrm{~g}$ sequestrene and $0.1 \mathrm{~g}$ urea). All volatile captures were done using $4-5$ weeks old plants.

\section{Treatments}

Brassica oleracea plants were either untreated, as control (CNT), or attacked by M. histrionica. Attacked plants were obtained by exposing them to two M. histrionica females, placed on the lower leaf surface inside a suitable "clip cage" (Ø $=3.8 \mathrm{~cm} ; \mathrm{h}=1 \mathrm{~cm}$; modified Petri dish with the rim covered by a small sponge ring), under controlled environmental conditions $\left(25 \pm 1{ }^{\circ} \mathrm{C}, 60 \pm 5 \% \mathrm{RH}\right.$ and photoperiod $\left.15 \mathrm{~L}: 9 \mathrm{D}\right)$ and removed after $24 \mathrm{~h}$. Volatiles were collected from plants subjected to the following treatments: feeding punctures $(\mathrm{F})$; combination of feeding punctures and oviposition of one egg mass (FO); feeding punctures and an hatched egg mass (FOH); just oviposition (O). Virgin females were used to obtain plants with only feeding punctures, and gravid females for plants subjected to both feeding and oviposition. The FOH plants were produced by keeping plants bearing an egg mass in a climatic chamber until the nymphs emergence $(\sim 7 \mathrm{~d})$. Just after emergence the $1^{\text {st }}$ instar nymphs, which do not feed until after moulting (Canerday, 1965), were removed using a fine brush. To obtain plants just oviposited on (O), gravid females with excised stylets were used. Ovipositing females were previously anaesthetized inside a glass tube with $\mathrm{CO}_{2}$ for $4-5 \mathrm{~s}$ in order to immobilize their labium. Afterwards their stylets were drawn from the labium with an entomological pin (no. 000) and half their length amputated with the aid of precision micro-scissors, a stereomicroscope (Zeiss ${ }^{\circledR}$ Stemi SV8) and optical fibre illumination (Intralux ${ }^{\circledR} 5000$ ). Because preliminary experiments showed that after stylet abscission females will not oviposit for about one day, the treated females were placed inside a plastic dish $(\varnothing=$ $12 \mathrm{~cm}$ ) for $24 \mathrm{~h}$ before they were placed on cabbage plants.

\section{Collection of plant volatiles}

The collection of volatiles was carried out over a period of 24 $\mathrm{h}$, randomly combining every day four of the five treatments $(\mathrm{F}$, $\mathrm{FO}, \mathrm{FOH}, \mathrm{O}$ and $\mathrm{CNT}$ ). In addition, in the case of plants with only feeding punctures (F) and those with feeding punctures and an egg mass (FO), the volatile collections were also made after intervals of $0-24 \mathrm{~h}, 24-48 \mathrm{~h}$ and $48-72 \mathrm{~h}$.

A cylindrical glass chamber $(\varnothing=13.5 \mathrm{~cm}$ i.d; $\mathrm{h}=19 \mathrm{~cm})$, with an o-ring sealed middle joint, was used to collect head- 
space volatiles in all the treatments. Before use the glass chamber was washed with water and detergent, rinsed with acetone and hexane, and kept in an oven at $\sim 180^{\circ} \mathrm{C}$. Air, purified by passage through an activated charcoal filter, was pumped at a flow of $\sim 1800 \mathrm{ml} / \mathrm{min}$ and switched in two chambers containing plants. The air was simultaneously ejected from each chamber at a rate of $600 \mathrm{ml} / \mathrm{min}$ and plant volatiles were trapped in a glass tube filled with Porapak Q (Sigma Aldrich; $60 \mathrm{mg}, 80-100$ mesh), which was pre-cleaned with hexane and then heat conditioned at least for $2 \mathrm{~h}$ in a stream of nitrogen $(100 \mathrm{ml} / \mathrm{min})$ at $130^{\circ} \mathrm{C}$. All entrainments were carried out in a temperaturecontrolled room $\left(24 \pm 1{ }^{\circ} \mathrm{C}, 60 \pm 5 \% \mathrm{RH}\right.$ and photoperiod $12 \mathrm{~L}$ : 12D; lights on from 8:00 to 20:00) under 8 fluorescent lamps (Philips Master TLD 58W/840) starting between $\sim 11.00-12.00$ am and ending $24 \mathrm{~h}$ later. In the case of entrainments collected at intervals, the Porapak traps were changed every $24 \mathrm{~h}$ and entrainments ended after $72 \mathrm{~h}$. Traps were eluted with $700 \mu \mathrm{l}$ of hexane, and the obtained extracts were successively concentrated to $100 \mu 1$ under a gentle stream of nitrogen.

\section{Calibration curves}

A set of calibration standard curves were obtained by using solutions of each standard compound dissolved in hexane at a range of concentrations from $20 \mathrm{ppm}$ to $0.2 \mathrm{ppm}$.

Good linearity was achieved with correlation coefficients between 0.9987 and 0.9995 . Both standard solutions and samples were analysed in the same way.

The limits of detection (LODs) (estimated to be 3 times the background noise) ranged from 0.5 to $1 \mathrm{ppb}$ for GLV and from 0.2 to $0.5 \mathrm{ppb}$ for the other chemicals.

\section{Gas chromatographic analysis (GC)}

Analyses of $2 \mu \mathrm{l}$ of each extract were performed on a Varian CP-3800 gas chromatograph equipped with a FID detector and an electronic pressure control (EPC). The split/splitless injector was operated in the split mode $(1: 10)$. Compounds were separated on a VF-1ms fused silica capillary column $(30 \mathrm{~m}, 0.32 \mathrm{~mm}$ i.d., $0.25 \mu \mathrm{m}$ film thickness, Varian, Palo Alto, CA, USA). The injector and detector operated at $260^{\circ} \mathrm{C}$ and $280^{\circ} \mathrm{C}$, respectively. The oven temperature was programmed as follows: from $40^{\circ} \mathrm{C}$ to $250^{\circ} \mathrm{C}\left(10\right.$-min hold) at $2^{\circ} \mathrm{C} / \mathrm{min}$. The EPC (10 Psi) was used to provide the desired carrier gas flow rates for the various experimental conditions. The carrier gas was ultrapure helium. The entire system was controlled by Galaxie software (Varian, version 1.8). Calibration graphs for the compounds were constructed by measuring peak heights $v s$. concentrations. Individual components were identified by injection of pure standard compounds and comparison with their retention times. After analysis, the compounds were quantified as percentage peak area using integration data.

\section{Chemicals}

Standard compounds of GLV (3-methyl-2-pentanone, $(E)$-2hexen-1-ol, (Z)-3-hexen-1-ol, $(E)$-3-hexen-1-ol, $(E)$-2-hexenal, (Z)-3-hexenal, (Z)-3-hexenyl acetate, hexyl alcohol, hexyl acetate, capronaldehyde), terpenes ( $\alpha$-thujene, $\alpha$-pinene, sabinene, $\beta$-pinene, myrcene, 1,4-cineole, 1,8-cineole, limonene, sabinene hydrate, linalool, trans-nerolidol, $(E)$ - $\beta$-caryophyllene, $(E, E)$ $\alpha$-farnesene and $(E)$ - $\beta$-ocimene), glucosinolate hydrolysis products (3-indolylacetonitrile, benzyl isothiocyanate, allyl isothiocyanate, benzyl cyanide, 4-methoxy-3-indolylacetonitrile), jasmonates (cis-jasmone and methyl jasmonate) and other compounds (methyl salicylate, indole, dodecane) were purchased from Sigma-Aldrich. GC pure hexane was also obtained from Sigma-Aldrich.

\section{Coupled gas chromatography-mass spectrometry (GC-MS)}

Confirmatory analyses were performed on a Saturn II GC-MS system (Varian, Walnut Creek, CA). Saturn WS software was used to check the instrument and collect the data. The GC was equipped with a VF-1 ms fused silica capillary column (Varian, $30 \mathrm{~m}, 0.32 \mathrm{~mm}$ i.d., $0.25 \mu \mathrm{m}$ film thickness). The carrier gas was ultrapure helium at a flow rate of $1 \mathrm{~mL} \mathrm{~min}^{-1}$.

The temperature program was from $40^{\circ} \mathrm{C}$ to $280^{\circ} \mathrm{C}(10$-min hold) at $2^{\circ} \mathrm{C} / \mathrm{min}$. The injection of $1 \mu \mathrm{l}$ of selected samples was in the splitless mode. The MSD was operated in electron impact (EI) mode at $70 \mathrm{eV}$. The MSD transfer line and injector temperatures were $280^{\circ} \mathrm{C}$ and $250^{\circ} \mathrm{C}$, respectively.

The components separated under the above conditions were identified using the NIST 98.1 mass spectral library.

\section{Statistical analysis}

The estimation of the percentage of each class of compounds (terpenes, jasmonates, glucosinolate derivatives - VGSs) and of each compound was obtained by calculating the ratio between their concentration values and the total concentration of detected VOCs of each plant. The data obtained for the volatiles collected over $24 \mathrm{~h}$ were analyzed by 1-way ANOVA (Statistica 6.0, Statsoft Inc., 2001). In the case of the volatiles collected at intervals the data were analyzed using a randomized block design analysis of variance (ANOVA) with plants as blocks. Before the analysis, Box-Cox transformation was used to reduce data heteroscedasticity (Sokal \& Rohlf, 1998).

\section{RESULTS}

\section{Volatile emission from healthy and attacked plants}

GC analysis showed differences in the proportions of volatile compounds released by $B$. oleracea var. sabauda subjected to different treatments.

The percentage of terpenes significantly decreased in the emissions from plants subjected to feeding and oviposition (FO) compared to the control (CNT) and other treatments, i.e. plants with feeding punctures $(\mathrm{F})$, with feeding punctures and one hatched egg mass $(\mathrm{FOH})$ and with a freshly deposited egg mass $(\mathrm{O})(F=8.30 ; d f=4$, 53; $P<0.001$ ) (Table 1). However, there were no significant differences in the terpene emissions from CNT, F, FOH and $O$ plants (Table 1).

As regards jasmonates, significant differences were found in the total emission (\%), which was higher in FO and $\mathrm{O}$ compared to the other treatments $(F=3.87 ; d f=4$, 53; $P=0.008$ ) (Table 1).

The total percentage of VGSs significantly increased in FO compared to all other treatments $(F=9.63 ; d f=3,44$; $P<0.001)$ except $\mathrm{O}$, where these compounds were not detected (Table 1).

Considering the specific terpenes with significant differences among treatments, the emission (\%) of $\alpha$-thujene $(F=5.64 ; d f=4,53 ; P<0.001)$ and sabinene $(F=5.09$; $d f=4,53 ; P=0.001)$ was significantly lower from FO compared to $\mathrm{CNT}$ and $\mathrm{FOH}$ plants. Moreover only in the case of $\alpha$-thujene, the emission from FO plants was lower than from $\mathrm{O}$ plants (Table 1). $\beta$-pinene was released at higher percentages by $\mathrm{O}$ compared to $\mathrm{F}$ and $\mathrm{FO}$ plants $(F$ $=4.13 ; d f=4,53 ; P=0.005)$ (Table 1$)$. The amount $(\%)$ of 1,8-cineole was higher in $\mathrm{O}$ compared to $\mathrm{F}(F=2.96$; $d f=3,43 ; P=0.042)$, whereas this compound was not detected in the emission from FO plants (Table 1). (E)- $\beta$ - 
TABLE 1. Mean percentage \pm SE of the different compounds in the total emission of volatiles collected from untreated B. oleracea plants (CNT) and those with feeding punctures (F), a combination of feeding punctures and oviposition (FO), feeding punctures plus one hatched egg mass $(\mathrm{FOH})$ and only oviposition $(\mathrm{O})$. Means followed by the same letter are not significantly different $(P>$ 0.05, 1-way ANOVA, Tukey HSD test); - not detected.

\begin{tabular}{|c|c|c|c|c|c|}
\hline \multirow[b]{2}{*}{ Compounds } & \multicolumn{5}{|c|}{ Treatments } \\
\hline & $\begin{array}{c}\text { CNT } \\
\mathrm{n}=12\end{array}$ & $\begin{array}{c}\mathrm{F} \\
\mathrm{n}=15\end{array}$ & $\begin{array}{c}\mathrm{FO} \\
\mathrm{n}=11\end{array}$ & $\begin{array}{c}\text { FOH } \\
\mathrm{n}=10\end{array}$ & $\begin{array}{c}\mathrm{O} \\
\mathrm{n}=10\end{array}$ \\
\hline$\alpha$-thujene & $5.55 \mathrm{a} \pm 0.12$ & $4.55 \mathrm{ab} \pm 0.36$ & $3.80 \mathrm{~b} \pm 0.44$ & $5.25 \mathrm{a} \pm 0.19$ & $5.29 \mathrm{a} \pm 0.33$ \\
\hline$\alpha$-pinene & $6.60 \mathrm{a} \pm 0.18$ & $7.17 \mathrm{a} \pm 0.85$ & $6.45 \mathrm{a} \pm 1.09$ & $5.72 \mathrm{a} \pm 0.21$ & $5.68 \mathrm{a} \pm 0.32$ \\
\hline sabinene & $27.67 \mathrm{a} \pm 0.40$ & $23.92 \mathrm{ab} \pm 1.62$ & $20.75 b \pm 2.08$ & $27.24 \mathrm{a} \pm 0.79$ & $24.83 \mathrm{ab} \pm 1.16$ \\
\hline ß-pinene & $2.53 \mathrm{ab} \pm 0.06$ & $2.16 b \pm 0.23$ & $1.95 \mathrm{~b} \pm 0.16$ & $2.56 \mathrm{ab} \pm 0.06$ & $3.65 \mathrm{a} \pm 0.47$ \\
\hline myrcene & $12.16 \mathrm{a} \pm 0.34$ & $12.22 \mathrm{a} \pm 0.87$ & $11.72 \mathrm{a} \pm 1.32$ & $12.60 \mathrm{a} \pm 0.60$ & $9.00 \mathrm{a} \pm 1.54$ \\
\hline 1,8-cineole & $5.69 \mathrm{ab} \pm 1.72$ & $3.59 \mathrm{~b} \pm 1.36$ & - & $7.08 \mathrm{ab} \pm 1.94$ & $10.03 \mathrm{a} \pm 1.20$ \\
\hline limonene & $31.69 \mathrm{a} \pm 1.71$ & $31.12 \mathrm{a} \pm 1.52$ & $29.47 \mathrm{a} \pm 1.37$ & $29.80 \mathrm{a} \pm 1.54$ & $28.45 \mathrm{a} \pm 1.63$ \\
\hline (E)-ß-ocimene & $2.20 \mathrm{a} \pm 0.22$ & $3.06 \mathrm{a} \pm 0.67$ & $3.55 \mathrm{a} \pm 1.07$ & $1.56 \mathrm{a} \pm 0.43$ & - \\
\hline sabinene hydrate & $1.42 \mathrm{a} \pm 0.51$ & $2.67 \mathrm{a} \pm 0.38$ & $2.29 \mathrm{a} \pm 0.45$ & $2.79 \mathrm{a} \pm 0.63$ & $3.42 \mathrm{a} \pm 0.44$ \\
\hline linalool & - & - & - & - & $3.83 \mathrm{a} \pm 1.44$ \\
\hline trans-nerolidol & $0.42 \mathrm{a} \pm 0.14$ & $1.08 \mathrm{a} \pm 0.41$ & $0.87 \mathrm{a} \pm 0.26$ & - & - \\
\hline (E)-ß-caryophyllene & $0.15 \mathrm{~b} \pm 0.07$ & $2.68 \mathrm{a} \pm 0.72$ & $4.50 \mathrm{a} \pm 0.71$ & - & - \\
\hline Total terpenes & $96.08 a \pm 0.69$ & $94.23 \mathrm{a} \pm 1.00$ & $85.34 b \pm 2.54$ & $94.61 \mathrm{a} \pm 1.73$ & $94.17 \mathrm{a} \pm 0.90$ \\
\hline cis-jasmone & - & $0.30 \mathrm{a} \pm 0.11$ & $0.50 \mathrm{a} \pm 0.15$ & - & - \\
\hline methyl jasmonate & $1.27 \mathrm{~b} \pm 0.35$ & $1.07 \mathrm{~b} \pm 0.33$ & $1.94 \mathrm{a} \pm 0.33$ & $1.21 \mathrm{~b} \pm 0.40$ & $3.81 \mathrm{a} \pm 1.05$ \\
\hline Total jasmonates & $1.27 b \pm 0.35$ & $1.37 \mathrm{~b} \pm \mathbf{0 . 4 0}$ & $2.45 \mathrm{a} \pm 0.42$ & $1.21 \mathrm{~b} \pm 0.40$ & $3.81 \mathrm{a} \pm 1.05$ \\
\hline 3-indolylacetonitrile & $0.87 \mathrm{a} \pm 0.23$ & $1.17 \mathrm{a} \pm 0.29$ & $1.47 \mathrm{a} \pm 0.33$ & $0.90 \mathrm{a} \pm 0.27$ & - \\
\hline 4-methoxy-3-indolylacetonitrile & - & $1.97 \mathrm{~b} \pm 0.66$ & $8.93 \mathrm{a} \pm 2.22$ & $2.18 \mathrm{~b} \pm 1.06$ & - \\
\hline Total VGSs & $0.87 b \pm 0.23$ & $3.14 \mathrm{~b} \pm 0.68$ & $10.39 \mathrm{a} \pm 2.34$ & $3.08 \mathrm{~b} \pm 1.20$ & - \\
\hline dodecane & $1.78 \mathrm{a} \pm 0.27$ & $1.26 \mathrm{a} \pm 0.22$ & $1.82 \mathrm{a} \pm 0.18$ & $1.10 \mathrm{a} \pm 0.34$ & $2.02 \mathrm{a} \pm 0.65$ \\
\hline
\end{tabular}

ocimene was not detected in $\mathrm{O}$, and there were no significant differences among the other treatments (Table 1). By contrast, the oxygenated monoterpene linalool was only detected in the volatile blend from $\mathrm{O}$ (Table 1). Transnerolidol was detected only in CNT, F and FO (Table 1). The emission $(\%)$ of the sesquiterpen (E)- $\beta$-caryophyllene from $\mathrm{FO}$ and $\mathrm{F}$ significantly increased compared to CNT $(F=25.28 ; d f=2,35 ; P<0.001)$, and was not detected from $\mathrm{FOH}$ and $\mathrm{O}$ plants (Table 1).

Considering jasmonates, cis-jasmone appeared to be induced only by FO and F and methyl jasmonate differed significantly among treatments, being highest in the case of FO and $\mathrm{O}(F=4.43 ; d f=4,53 ; P=0.004)$ (Table 1).

As regards the VGSs, 3-indolylacetonitrile was not detected in $\mathrm{O}$, instead, 4-methoxy-3-indolylacetonitrile showed a significant increase in $\mathrm{FO}$ compared with $\mathrm{F}$ and FOH $(F=6.37 ; d f=2,33 ; P=0.005)$ and not detected in $\mathrm{CNT}$ and $\mathrm{O}$ (Table 1).

\section{Volatile emission at different time intervals from plants with feeding punctures (F)}

The percentage of the four chemical classes in volatiles from $B$. oleracea plants did not change significantly with time (0-24 h, 24-48 h and 48-72 h) (Table 2). Considering the specific compounds, only for two terpenes were the differences significant. Trans-nerolidol was detected only during the first $0-24 \mathrm{~h}$, whereas the emission (\%) of (E)- $\beta$-caryophyllene, which increased from similarly damaged plants in the previous experiments (see previous section and Table 1), started decreasing 48-72 $\mathrm{h}$ after treatment $(F=4.48 ; d f=2,12 ; P=0.035)$ (Table 2).

\section{Volatile emission at different time intervals from plants with a combination of feeding punctures and oviposition (FO)}

During the $24-48 \mathrm{~h}$ and $48-72 \mathrm{~h}$ time intervals, the percentage of total terpene emissions, which decreased from FO cabbage plants (see above and Table 1), increased compared to the first interval $(0-24 \mathrm{~h})(F=11.99 ; d f=2$, $10 ; P=0.002$ ) (Table 2). In contrast, the volatile compounds derived from glucosinolates (VGSs) decreased continuously over the three time intervals $(F=12.98 ; d f=$ 2,$10 ; P=0.002$ ) (Table 2).

Considering the single terpenoids, the percentage emission of $\alpha$-thujene $(F=7.91 ; d f=2,10 ; P=0.009)$, sabinene $(F=7.03 ; d f=2,10 ; P=0.012), \beta$-pinene $(F=$ 4.90; $d f=2,10 ; P=0.033)$, myrcene $(F=4.23 ; d f=2$, $10 ; P=0.047)$ and limonene $(F=12.82 ; d f=2,10 ; P=$ $0.002)$ generally increased over the three time intervals, although such increase was not significant at the third interval for $\beta$-pinene (Table 2). Trans-nerolidol was only detected during the first $(0-24 \mathrm{~h})$ and the second (24-48 h) time interval, and the emission (\%) of the sesquiterpene $(E)$ - $\beta$-caryophyllene decreased significantly in the last time interval compared to the first and second $(F=$ 35.89; $d f=2,10 ; P<0.001$ ) (Table 2). 
TABLE 2. Mean percentage \pm SE of the different compounds in the total emission of volatiles collected from B. oleracea plants with feeding punctures $(\mathrm{F})$ and those with a combination of feeding punctures and oviposition (FO) at different time intervals $(0-24$ $\mathrm{h}, 24-48 \mathrm{~h}$ and $48-72 \mathrm{~h})$. Means followed by the same letter are not significantly different $(P>0.05,2$-way ANOVA, Tukey HSD test); - not detected.

\begin{tabular}{|c|c|c|c|c|c|c|}
\hline \multirow{3}{*}{ Compounds } & \multicolumn{3}{|c|}{$\begin{array}{l}\text { Plants with feeding punctures (F) } \\
\qquad \mathrm{n}=7\end{array}$} & \multicolumn{3}{|c|}{$\begin{array}{l}\text { Plants with feeding punctures and egg mass (FO) } \\
\qquad \mathrm{n}=6\end{array}$} \\
\hline & \multicolumn{3}{|c|}{ Time intervals } & \multicolumn{3}{|c|}{ Time intervals } \\
\hline & $0-24 \mathrm{~h}$ & $24-48 \mathrm{~h}$ & $48-72 \mathrm{~h}$ & $0-24 \mathrm{~h}$ & $24-48 \mathrm{~h}$ & $48-72 \mathrm{~h}$ \\
\hline$\alpha$-thujene & $4.92 \mathrm{a} \pm 0.28$ & $5.17 \mathrm{a} \pm 0.49$ & $5.26 \mathrm{a} \pm 0.15$ & $3.99 b \pm 0.19$ & $4.61 \mathrm{ab} \pm 0.27$ & $4.92 \mathrm{a} \pm 0.13$ \\
\hline$\alpha$-pinene & $6.24 \mathrm{a} \pm 0.38$ & $5.80 \mathrm{a} \pm 0.61$ & $5.79 \mathrm{a} \pm 0.19$ & $5.29 \mathrm{a} \pm 0.18$ & $5.70 \mathrm{a} \pm 0.30$ & $5.32 \mathrm{a} \pm 0.28$ \\
\hline sabinene & $26.00 \mathrm{a} \pm 1.10$ & $27.93 \mathrm{a} \pm 1.91$ & $26.97 \mathrm{a} \pm 0.36$ & $20.66 b \pm 0.86$ & $24.88 \mathrm{a} \pm 1.37$ & $25.91 \mathrm{a} \pm 0.30$ \\
\hline ß-pinene & $2.53 \mathrm{a} \pm 0.11$ & $2.47 \mathrm{a} \pm 0.22$ & $2.46 \mathrm{a} \pm 0.04$ & $1.99 \mathrm{~b} \pm 0.05$ & $2.38 \mathrm{a} \pm 0.14$ & $2.30 \mathrm{ab} \pm 0.09$ \\
\hline myrcene & $11.09 \mathrm{a} \pm 0.48$ & $12.02 \mathrm{a} \pm 0.65$ & $11.52 \mathrm{a} \pm 0.15$ & $9.52 b \pm 0.50$ & $8.70 b \pm 1.81$ & $11.03 \mathrm{a} \pm 0.30$ \\
\hline 1,8-cineole & $6.10 \mathrm{a} \pm 2.16$ & $6.52 \mathrm{a} \pm 2.31$ & $6.41 \mathrm{a} \pm 2.27$ & - & - & - \\
\hline limonene & $29.30 \mathrm{a} \pm 2.01$ & $27.24 \mathrm{a} \pm 2.82$ & $30.94 \mathrm{a} \pm 2.14$ & $28.97 \mathrm{~b} \pm 1.19$ & $33.84 \mathrm{a} \pm 1.26$ & $36.20 \mathrm{a} \pm 0.48$ \\
\hline (E)-ß-ocimene & $2.15 \mathrm{a} \pm 0.37$ & $2.27 \mathrm{a} \pm 0.41$ & $2.42 \mathrm{a} \pm 0.12$ & $2.26 \mathrm{a} \pm 0.47$ & $1.83 \mathrm{a} \pm 0.59$ & $2.44 \mathrm{a} \pm 1.19$ \\
\hline sabinene hydrate & $2.97 \mathrm{a} \pm 0.56$ & $3.71 \mathrm{a} \pm 0.28$ & $3.62 \mathrm{a} \pm 0.09$ & $2.50 \mathrm{a} \pm 0.50$ & $3.51 \mathrm{a} \pm 0.26$ & $3.53 \mathrm{a} \pm 0.17$ \\
\hline linalool & - & - & - & - & - & - \\
\hline trans-nerolidol & $0.54 \pm 0.25$ & - & - & $0.56 \mathrm{a} \pm 0.25$ & $0.41 \mathrm{a} \pm 0.18$ & - \\
\hline (E)-ß-caryophyllene & $1.67 \mathrm{ab} \pm 0.88$ & $2.05 \mathrm{a} \pm 0.87$ & $0.86 \mathrm{~b} \pm 0.27$ & $4.54 \mathrm{a} \pm 0.69$ & $3.64 \mathrm{a} \pm 0.48$ & $1.39 \mathrm{~b} \pm 0.20$ \\
\hline Total terpenes & $93.50 \mathrm{a} \pm 1.64$ & $95.16 \mathrm{a} \pm 0.85$ & $96.24 \mathrm{a} \pm 0.71$ & $80.29 b \pm 2.94$ & $89.52 \mathrm{a} \pm 2.98$ & $93.04 a \pm 0.67$ \\
\hline cis-jasmone & - & - & - & $0.44 \pm 0.17$ & - & - \\
\hline methyl jasmonate & $0.99 \mathrm{a} \pm 0.39$ & $1.69 \mathrm{a} \pm 0.19$ & $0.85 \mathrm{a} \pm 0.24$ & $2.30 \mathrm{a} \pm 0.16$ & $2.27 \mathrm{a} \pm 0.16$ & $2.34 \mathrm{a} \pm 0.40$ \\
\hline Total jasmonates & $0.99 a \pm 0.39$ & $1.69 \mathrm{a} \pm 0.19$ & $0.85 \mathrm{a} \pm \mathbf{0 . 2 4}$ & $2.74 a \pm 0.22$ & $2.27 \mathrm{a} \pm 0.16$ & $2.34 \mathrm{a} \pm 0.40$ \\
\hline 3-indolylacetonitrile & $0.76 \mathrm{a} \pm 0.26$ & $0.38 \mathrm{a} \pm 0.30$ & $0.80 \mathrm{a} \pm 0.25$ & $1.90 \mathrm{a} \pm 0.43$ & $1.11 \mathrm{ab} \pm 0.43$ & $0.23 \mathrm{~b} \pm 0.15$ \\
\hline 4-methoxy-3-indolylacetonitrile & $3.51 \mathrm{a} \pm 1.10$ & $1.35 \mathrm{a} \pm 0.66$ & $0.78 \mathrm{a} \pm 0.58$ & $12.96 \mathrm{a} \pm 2.82$ & $5.08 \mathrm{~b} \pm 3.08$ & $2.35 \mathrm{~b} \pm 0.32$ \\
\hline Total VGSs & $4.29 \mathrm{a} \pm 1.32$ & $1.35 \mathrm{a} \pm 0.66$ & $1.59 \mathrm{a} \pm 0.49$ & $14.87 \mathrm{a} \pm 2.88$ & $6.19 b \pm 2.85$ & $2.58 \mathrm{~b} \pm 0.32$ \\
\hline dodecane & $1.22 \mathrm{a} \pm 0.39$ & $1.80 \mathrm{a} \pm 0.23$ & $1.32 \mathrm{a} \pm 0.12$ & $2.10 \mathrm{a} \pm 0.19$ & $2.02 \mathrm{a} \pm 0.16$ & $2.05 \mathrm{a} \pm 0.26$ \\
\hline
\end{tabular}

Although total emission (\%) of jasmonates did not differ significantly in the three intervals (Table 2), the octadecanoic-derived cis-jasmone was detected only during the first time interval (0-24 h) (Table 2) and was not emitted by undamaged plants (see also Table 1$)$.

The total VGSs $(F=12.98 ; d f=2,10 ; P=0.002)$, as well as the single compounds 3 -indolylacetonitrile $(F=$ $6.13 ; d f=2,10 ; P=0.018)$ and 4-methoxy-3indolylacetonitrile $(F=6.88 ; d f=2,10 ; P=0.013)$, which were also higher in damaged compared to undamaged plants (see also Table 1), significantly decreased with increasing time intervals (Table 2).

\section{DISCUSSION}

Feeding and oviposition by Murgantia histrionica on Brassica oleracea, especially when combined, induce a change in the percentage emission of several constitutive volatiles compared with those released by healthy plants, and the release de novo of linalool after oviposition (Table 1).

The most significant difference among the treatments was in terpene compounds. Specifically, the proportion of $\alpha$-thujene, sabinene, $\beta$-pinene and 1,8-cineole decreased in the emissions from attacked plants, and only the sesquiterpene (E)- $\beta$-caryophyllene increased significantly, although it was not detected in the $\mathrm{FOH}$ and $\mathrm{O}$ treatments
(Table 1). The changes in the emission of such compounds occurred rapidly during the first $24 \mathrm{~h}$ and then increased or declined during the following 48-72 $\mathrm{h}$ (Table 2).

Plants attacked by insects commonly emit terpenes (Paré \& Tumlinson, 1997b, 1999; Kessler \& Baldwin, 2001) as do plants damaged by other causes (Agelopoulos et al., 1999). A rapid increase in terpene emissions is also recorded for broad beans with egg masses and feeding punctures made by Nezara viridula (Colazza et al., 2004b). In contrast, there is a latency period between the initial stimulus and the resulting increase in terpenes induced by other insects (Paré \& Tumlinson, 1997a; Kessler \& Baldwin, 2001). In the case of $(E)-\beta$ caryophyllene, previous studies record an increase in the production of this sesquiterpene by plants damaged mechanically, by herbivore feeding or a combination of feeding and oviposition (Turlings et al., 1998a; Agelopoulos et al., 1999; Wegener et al., 2001; Gouinguené \& Turlings, 2002; Rodriguez-Saona et al., 2002; Colazza et al., 2004b). In the B. oleracea - M. histrionica system investigated here, oviposition per se did not induce plants to emit $(E)$ - $\beta$-caryophyllene since this compound was not detected in the emissions of plants only subjected to oviposition (Table 1). Instead (E)- $\beta$-caryophyllene was detected in the highest amounts (\%) for plants subjected 
to feeding and oviposition (Table 1), suggesting a synergistic action, similar to that recorded in the Vicia faba / Phaseolus vulgaris $-N$. viridula system (Colazza et al., $2004 a, b)$. The effect of substances present on egg surfaces and/or in the follicular secretion combined with the effect of the saliva or just feeding damage might enhance the release of this compound.

Unlike the terpenes reported above, linalool appeared to be released de novo by plants with only oviposition (Table 1). This monoterpene is not detected in the emission from healthy cabbage and Brussels sprouts but it is emitted by these plants when damaged by Plutella xylostella (Lepidoptera: Plutellidae) (Bukovinszky et al., 2005; Pinto et al., 2007).

The emission of $(E)$ - $\beta$-ocimene, present in healthy and damaged cabbage plants, was not detected from plants with only oviposition (Table 1), confirming that oviposition by this bug, in the absence of feeding, is able to cause changes in the emission of volatile compounds by cabbage plants.

The percentage emission of the two jasmonate compounds increased when the plants were infested by $M$. histrionica (Table 1). These endogenous chemical signals are produced by many plants (Preston et al., 2001) and their volatile derivatives are involved in plant responses following mechanical, herbivore or pathogen stress (Walling, 2000). In the system B. oleracea - M. histrionica, cis-jasmone was induced by a combination of feeding and oviposition, whereas methyl jasmonate was induced just by oviposition. These results suggest that the lipoxygenase pathway may be activated by the bug's activity on the host plant, whereas the defence signal methyl salicylate was not detected. Plant responses to insects are generally distinctive and dependent on their different feeding habits. Phloem feeders such as aphids and whiteflies induce the SA pathway, commonly activated also by bacterial, fungal and viral pathogens, whilst cell-content feeders such as thrips induce the JA pathway (Walling, 2000). Studies on piercing sucking insects like Lygus hesperus Knight (Heteroptera: Miridae) and $N$. viridula suggest that the mechanisms of volatile induction are similar to those induced by chewing insects (Williams et al., 2005). Consequently in the case of cabbage attacked by $M$. histrionica it is possible to hypothesize the activation of a JA-dependent wound-signal transduction pathway. In fact, the increased emission of methyl jasmonate does not change over the $72 \mathrm{~h}$ period, and cisjasmone is not detected after $24 \mathrm{~h}$ (Table 2). This result confirms that in plants stressed by biotic or abiotic factors, the maximum emission of this hormonesignalling molecule occurs after 12-24 h (Lee et al., 2004; Zadra et al., 2006).

An interesting result concerns the volatile compounds derived from glucosinolates (VGSs). In general the glucosinolates are considered to be the major chemical defence of crucifers and they normally occur in low concentrations (Mattiacci et al., 2001a). Previous studies show that their production is enhanced by insect damage (Koristas et al., 1991; Bodnaryk, 1994; Mattiacci et al.,
1994, 2001b; Agrawal et al., 1999; Walling, 2000). In the $B$. oleracea - M. histrionica system two glucosinolate hydrolysis products (VGSs) were identified, 3-indolylacetonitrile and 4-methoxy-3-indolylacetonitrile. These compounds are formed by the hydrolysis of glucobrassicin and 4-methoxy-glucobrassicin, respectively. The latter especially was emitted in large amount by plants with feeding punctures plus oviposition (Table 1), suggesting a possible synergistic action. The emission of 4-methoxy-3-indolylacetonitrile decreased after $24 \mathrm{~h}$ (Table 2). Indole-derivatives are the most potent class of glucosinolates for attracting several crucifer-feeding insects (Bartlet et al., 1999) and even if these chemicals can be used as plant defense, they are supposed to be important cues used by specialist herbivores for recognition, oviposition, and feeding (Agrawal \& Kurashige, 2003).

In the analyses of $B$. oleracea volatiles, GLVs were never detected. This contrasts with other systems involving the same plant species attacked by chewing insects (Mattiacci et al., 2001b; Fatouros et al., 2005; Bukovinszky et al., 2005; Geervliet et al., 1997; Pinto et al., 2007) or other plant species attacked by piercingsucking insects (Rodriguez-Saona et al., 2002; Colazza et al., 2004b). This inconsistency might be due to the infestation level (Dicke et al., 1993; Tumlinson et al., 1993), which was very low in the case of air entrainments from $B$. oleracea attacked by $M$. histrionica (2 adults per plant), and/or to the fact that, in our experiments, the air entrainments were not conducted contemporarily with the insect attack, i.e., the insects were removed before the capture of volatiles began.

Interestingly the change in the emission of terpenes, jasmonates and VGSs observed after an egg mass was deposited on the host plant, either with or without feeding, returned to levels similar to those from the control when the eggs hatched. A similar response was observed in the $V$. faba $-N$. viridula system, where the emission of several compounds decreases after egg hatch (Colazza et al., 2004b). These results can be interpreted as a plant adaptation to the decrease in time of host egg suitability to parasitoid attack. Many plants have developed indirect induced defences against herbivores, thus attracting or activating the searching behaviour of natural enemies associated with the herbivore (Dicke et al., 1993; De Moraes et al., 1998). In the specific case of pentatomid bugs, indirect defences are induced by oviposition combined with feeding, which result in the emission of volatile compounds that attract egg parasitoids (Colazza et al., 2004a) or through changes in the chemical composition of the plant surface that stimulates parasitoid searching behaviour on the substrate (Conti et al., 2006). These responses, however, disappear when the bug eggs are no longer suitable for parasitoid attack, thus avoiding useless metabolic costs (Cipollini et al., 2003) by the plant and waste of time by the parasitoid (Colazza et al., 2004a). The changes in the emission of plant volatiles that are induced in $B$. oleracea as a consequence of oviposition and feeding by $M$. histrionica, therefore, may be 
involved in the recruitment of egg parasitoids, such as Trissolcus brochymenae (Ashmead) (Hymenoptera: Scelionidae), thus providing additional, highly reliable and detectable cues to those originating from the host bug (Conti et al., 2003).

In conclusion, this research reveals the effects of the feeding and reproductive activity of herbivorous bugs on the induction of volatile compounds in cabbage plants. Future research should focus on the role of such volatiles in the plant-herbivore-parasitoid interactions.

ACKNOWLEDGEMENTS. The authors are grateful to $\mathrm{S}$. Colazza for revising an early version of this manuscript. We also gratefully acknowledge the assistance of A. Luchetti in rearing Murgantia histrionica. This research was financially supported by MiUR - Ministero dell'Università e della Ricerca Scientifica e Tecnologica (PRIN-Cofin 2004 "Difese dirette ed indirette nelle piante agrarie per un controllo sostenibile di insetti dannosi").

\section{REFERENCES}

Agelopoulos N.G., Hooper A.M., Maniar S.P., Pickett J.A. \& WADHAMS L.J. 1999: A novel approach for isolation of volatile chemicals released by individual leaves of a plant in situ. J. Chem. Ecol. 25: 1411-1425.

Agrawal A.A. \& Kurashige N.S. 2003: A role for isothiocyanates in plant resistance against the specialist herbivore Pieris rapae. J. Chem. Ecol. 29: 1403-1415.

Agrawal A.A., Tuzun S. \& Bent E. 1999: Induced Plant Defences Against Pathogens and Herbivores. APS Press, St Paul, MO, 403 pp.

Alborn H.T., Turlings T.C.J., Jones T.H., Stenhagen G., Loughrin J.H. \& TumLinson J.H. 1997: An elicitor of plant volatiles from beet armyworm oral secretion. Science 276: 945-949.

Ament K., Kant M.R., Sabelis M.W., Haring M.A. \& SCHUURINK R.C. 2004: Jasmonic acid is a key regulator of spider mite-induced volatile terpenoid and methyl salicylate emission in tomato. Plant Physiol. 135: 2025-2037.

Arimura G., Kost C. \& Boland W. 2005: Herbivore-induced, indirect plant defences. Biochim. Biophys. Acta - Mol. Cell Biol. Lipids 1734: 91-111.

Bartlet E., Kiddle G., Williams I. \& Wallsgrove R. 1999: Wound-induced increases in the glucosinolate content of oilseed rape and their effect on subsequent herbivory by a crucifer specialist. Entomol. Exp. Appl. 91: 163-167.

Bernasconi M.L., Turlings T.C.J., Ambrosetti L., Bassetti P. \& DorN S. 1998: Herbivore-induced emissions of maize volatiles repel the corn leaf aphid, Rhopalosiphum maidis. Entomol. Exp. Appl. 87: 133-142.

BoDnARYK R.P. 1994: Potent effect of jasmonate on indole glucosinolates on oilseed rape and mustard. Phytochemistry 35: 301-305.

Bukovinszky T., Gols R., Posthumus M.A., Vet L.E.M. \& Van LENTEREN J.C. 2005: Variation in plant volatiles and attraction of the parasitoid Diadema semiclausum. J. Chem. Ecol. 31: $461-480$

Canerday T.D. 1965. On the biology of the harlequin bug, Murgantia histrionica (Hemiptera: Pentatomidae). Ann. Entomol. Soc. Am. 58: 931-932.

Cardoza Y.J., Alborn H.T. \& Tumlinson J.H. 2002: In vivo volatile emissions from peanut plants induced by simultaneous fungal infection and insect damage. J. Chem. Ecol. 28: $161-174$.
Cipollini D., Purrington C.B. \& Bergelson J. 2003: Costs of induced responses. Basic Appl. Ecol. 4: 79-85.

Colazza S., Fucarino A., Peri E., Salerno G., Conti E. \& Bin F. 2004a: Insect oviposition induces volatiles emission in herbaceous plant that attracts egg parasitoids. J. Exp. Biol. 207: $47-53$.

Colazza S., Mcelfresh J.S. \& Millar J.G. 2004b: Identification of volatile synomones, induced by Nezara viridula feeding and oviposition on bean spp. that attract the egg parasitoid Trissolcus basalis. J. Chem. Ecol. 5: 939-958.

Conti E., Salerno G., Bin F., William H.J. \& Vinson S.B. 2003: Chemical cues from Murgantia histrionica eliciting host location and recognition in the egg parasitoid Trissolcus brochymenae. J. Chem. Ecol. 29: 115-130.

Conti E., Salerno G., De Santis F., Leombruni B. \& Bin F. 2006: Difese indirette delle piante: i sinomoni per contatto indotti da ovideposizione. Atti Accad. Naz. Ital. Entomol. Rd. 54: 129-148.

Cortesero A.M., Stapel J.O. \& Lewis W.J. 2000: Understanding and manipulating plant attributes to enhance biological control. Biol. Contr. 17: 35-49.

De Bruxelles G. \& Roberts M.R. 2001: Signals regulating multiple responses to wounding and herbivores. Crit. Rev. Plant Sci. 20: 487-521.

Degenhardt J., Gershenzon J., Baldwin I.T. \& Kessler A. 2003: Attracting friends to feast on foes: engineering terpene emission to make crop plants more attractive to herbivore enemies. Curr. Opin. Biotechnol. 14: 169-176.

De Moraes C.M., Lewis W.J., Paré P.W., Alborn H.T. \& TumLINSON J.H. 1998: Herbivore infested plants selectively attract parasitoids. Nature 393: 570-573.

Dicke M. \& Sabelis M.W. 1988: How plants obtain predatory mites as bodyguards. Neth. J. Zool. 38: 148-165.

Dicke M., Van Baarlen P., Wessels R. \& Dijkman H. 1993: Herbivory induces systemic production of plant volatiles that attract predators of the herbivore: extraction of endogenous elicitor. J. Chem. Ecol. 19: 581-599.

Doughty K.J., Porter A.J.R., Morton A.M., Kiddle G., Bock C.H. \& Wallsgrove R.M. 1991: Variation in the glucosinolate content of oilseed rape (Brassica napus L.) leaves. II. Response to infection by Alternaria brassicae (Berk.) Sacc. Ann. Appl. Biol. 118: 469-477.

Doughty K.J., Kiddle G.A., Pye B.J., Wallsgrove R.M. \& PicketT J.A. 1995: Selective induction of glucosinolates in oilseed rape leaves by methyl jasmonate. Phytochemistry 38: 347-350.

Du Y.J., Poppy G.M., Powell W., Pickett J.A., Wadhams L.J. \& Woodcock C.M. 1998: Identification of semiochemicals released during aphid feeding that attract parasitoid Aphidius ervi. J. Chem. Ecol. 24: 1355-1368.

Farmer E.E., Almeras E. \& Krishnamurthy V. 2003: Jasmonate and related oxylipins in plant responses to pathogenesis and herbivory. Curr. Opin. Plant. Biol. 6: 372-378.

Fatouros N.E., Van Loon J.J.A., HordiJK K.A., Smid H.M. \& DiCKE M. 2005: Herbivore-induced plant volatiles mediate inflight host discrimination by parasitoids. J. Chem. Ecol. 9: 2033-2047.

Geervliet J.B.F., Posthumus M.A., Vet L.E.M. \& Dicke M. 1997: Comparative analysis of headspace volatiles from different caterpillar infested or uninfested food plants of Pieris species. J. Chem. Ecol. 12: 2935-2954.

GouinguenÉ S.P. \& TurLings T.C.J. 2002: The effects of abiotic factors on induced volatile emissions in corn plants. Plant Physiol. 129: 1296-1307. 
Green T.R. \& Ryan C.A. 1972: Wound-induced proteinase inhibitor in plant leaves: a possible defense mechanism against insects. Science 175: 776-777.

Guerrieri E., Poppy G.M., Powell W., Tremblay E. \& PennacCHIO F. 1999: Induction and systemic release of herbivoreinduced plant volatiles mediating in-flight orientation of Aphidius ervi. J. Chem. Ecol. 25: 1247-1261.

Halitschke R., Schittko U., Pohnert G., Boland W. \& BALDWIN I.T. 2001: Molecular interactions between the specialist herbivore Manduca sexta (Lepidoptera, Sphingidae) and its natural host Nicotiana attenuata. III. Fatty acid amino acid conjugates in herbivore oral secretions are necessary and sufficient for herbivore-specific plant responses. Plant Physiol. 125: 711-717.

HALKiER B.A. \& LiangCheng D. 1997: The biosynthesis of glucosinolates. Trends Plant Sci. 2: 425-431.

HILKER M. \& MEINERS T. 2002: Induction of plant responses to oviposition and feeding by herbivorous arthropods: A comparison. Entomol. Exp. Appl. 104: 181-192.

HiLKer M. \& MeIners T. 2006: Early herbivore alert: Insect eggs induce plant defence. J. Chem. Ecol. 32: 1379-1397.

Hilker M., Kobs C., Varama M. \& Schrank K. 2002: Insect egg deposition induces Pinus to attract egg parasitoids. J. Exp. Biol. 205: 455-461.

Hopkins R.J., Еквом B. \& HenKow L. 1998: Glucosinolate content and susceptibility for insect attack of three populations of Sinapsis alba. J. Chem. Ecol. 24: 1203-1216.

Johnson C.B., Kirby J., Naxakis G. \& Pearson S. 1999: Substantial UV-B-mediated induction of essential oils in sweet basil (Ocimum basilicum L.). Phytochemistry 51: 507-510.

Kessler A. \& Baldwin I.T. 2001: Defensive function of herbivore-induced plant volatile emissions in nature. Science 291: 2141-2144.

Koristas V.M., Lewis J.A. \& Fenwick G.R. 1991: Glucosinolate responses of oilseed rape, mustard and kale to mechanical wounding and infestation by cabbage stem flea beetle Psylloides chrysocephala. Ann. Appl. Biol. 118: 209-221.

LeE A., CHO K. \& JANG S. 2004: Inverse correlation between jasmonic acid and salicylic acid during early wound response in rice. Biochem. Bioph. Res. Commun. 318: 734-738.

Mattiacci L., Rudelli S., Rocca B.A., Genini S. \& Dorn S. 2001a: Systemically-induced response of cabbage plants against a specialist herbivore, Pieris brassicae. Chemoecology 11: 167-173.

Mattiacci L., Rocca B.A., Scascighini N., D’alessandro M., Hern A. \& Dorn S. 2001b: Systemically induced plant volatiles emitted at the time of "danger". J. Chem. Ecol. 11: 2234-2253.

Mattiacci L., Dicke M. \& Posthumus M.A. 1994: Induction of parasitoid attracting synomone in Brussels-sprouts plants by feeding of Pieris brassicae larvae: role of mechanical damage and herbivore elicitor. J. Chem. Ecol. 20: 2229-2247.

McPherson J.E. 1982: The Pentatomidea (Hemiptera) of Northeastern North America with Emphasis on the Fauna of the Illinois. Southern Illinois University Press, Carbondale, IL, $240 \mathrm{pp}$.

Meiners T. \& HiLKer M. 2000: Induction of plant synomones by oviposition of a phytophagous insect. J. Chem. Ecol. 26: 221-232.

Mithöfer A., Schulze B. \& Boland W. 2004: Biotic and heavy metal stress response in plants: evidence for common signals. FEBS Letters 566: 1-5.

MithöFer A., WanNer G. \& Boland W. 2005: Effects of feeding Spodoptera littoralis on lima bean leaves. II. Continuous mechanical wounding resembling insect feeding is sufficient to elicit herbivory-related volatile emission. Plant Physiol. 137: $1160-1168$.

Ninemets Ü., Loreto F. \& Reichstein M. 2004: Physiological and physico-chemical controls on foliar volatile organic compound emissions. Trends Plant Sci. 9: 180-186.

PARÉ P.W. \& TumLInson J.H. 1997a: De novo biosynthesis of volatiles induced by insect herbivory in cotton plants. Plant Physiol. 114: 1161-1167.

Paré P.W. \& Tumlinson J.H. 1997b: Induced synthesis of plant volatiles. Nature 385: 30-31.

Paré P.W. \& Tumlinson J.H. 1999: Plant volatiles as a defense against insect herbivores. Plant Physiol. 121: 325-331.

Pinto D.M., Blande J.D., Nykänen R., Dong W.X., Nerg A.M. \& Holopainen J.K. 2007: Ozone degrades common herbivoreinduced plant volatiles: does this affect herbivore prey location by predators and parasitoids? J. Chem. Ecol. 33: 683-694.

Potting R.P.J., Vet L.E.M. \& Dicke M. 1995: Host microhabitat location by the stemborer parasitoid Cotesia flavipes: The role of locally and systemically induced plant volatiles. $J$. Chem. Ecol. 21: 525-539.

Preston C.A., Laue G. \& Balwin I.T. 2001: Methyl jasmonate is blowing in the wind, but can it act as a plant-plant airborne signal? Biochem. Syst. Ecol. 29: 1007-1023.

Renwick J.A.A., Haribal M., Gouinguené S. \& Stadler E. 2006: Isothiocyanates stimulating oviposition by the Diamondback Moth, Plutella xylostella. J. Chem. Ecol. 32: $755-766$.

Rodriguez-Saona C., Crafts-Brandner S., Williams L. III \& PArÈ P.W. 2002: Lygus hesperus feeding and salivary gland extracts induce volatile emission in plants. J. Chem. Ecol. 28: 1733-1747.

Rojo E., Solano R. \& Sanchez-Serrano J.J. 2003: Interactions between signaling compounds involved in plant defense. $J$. Plant Growth Regul. 22: 82-98.

Schmelz E.A., Alborn H.T. \& Tumlinson J.H. 2001: The influence of intact-plant and excised-leaf bioassay designs on volicitin- and jasmonic acid-induced sesquiterpene volatile release in Zea mays. Planta 214: 171-179.

SoKal R.R. \& RohLF F.J. 1998: Biometry. W.E. Freeman, New York, NY, 852 pp.

Statsoft Inc. 2001: Statistica (Data Analysis Software System), Version 6. StatSoft Italia S.r.1., Vigonza (Pd), Italy.

TAKabayashi J. \& Dicke M. 1996: Plant-carnivore mutualism through herbivore-induced carnivore attractants. Trends Plant Sci. 1: 109-113.

Takabayashi J., Dicke M. \& Posthumus M.A. 1994: Volatile herbivore-induced terpenoids in plant mite interactions: variation caused by biotic and abiotic factors. J. Chem. Ecol. 20: 1329-1354.

Thaler J.S., Fidantsef A.L. \& Bostock M. 2002: Antagonism between jasmonate- and salicylate-mediated induced plant resistance: effects of concentration and timing elicitation on defense-related proteins, herbivore, and pathogen performance in tomato. J. Chem. Ecol. 28: 1131-1159.

Tumlinson J.H., Lewis W.J. \& Vet L.E.M.. 1993: How parasitic wasps find their hosts. Sci. Am. 268: 101-105.

Turlings T.C.J., Tumlinson J.H. \& Lewis W.J. 1990: Exploitation of herbivore-induced plant odors by host-seeking parasitic wasps. Science 250: 1251-1253.

Turlings T.C.J., Lengwiler U.B., Bernasconi M.L. \& WeChSLER D. 1998a: Timing of induced volatile emissions in maize seedlings. Planta 207: 146-152.

Turlings T.C.J., Bernasconi M., Bertossa R., Bigler F., Caloz G. \& Dorn S. 1998b: The induction of volatile emission in 
maize by three herbivore species with different feeding habits: possible consequences for their natural enemies. Biol. Contr. 11: 122-129.

VAN Poecke R.M.P. \& Dicke M.. 2004: Indirect defence of plants against herbivores: Using Arabidopsis thaliana as a model plant. Plant Biol. 6: 387-401.

Vuorinen T., Nerg A.N. \& Holopainen J.K. 2004a: Ozone exposure trigger the emission of herbivore-induced plant volatiles, but does not disturb tritrophic signalling. Environ. Pollut. 131: 305-311.

Vuorinen T., Reddy G.V.P., Nerg A.N. \& Holopainen J.K. 2004b: Monoterpene and herbivore-induced emissions from cabbage plants grown at elevated atmospheric $\mathrm{CO}_{2}$ concentration. Atmos. Environ. 38: 675-682.

WALLING L.L. 2000: The myriad plant responses to herbivores. J. Plant Growth Regul. 19: 195-216.
Weggener R., Schulz S., Meiners T., Hadwich K. \& Hilker M. 2001: Analysis of volatiles induced by oviposition of elm leaf beetle Xanthogaleruca luteola on Ulmus minor. J. Chem. Ecol. 27: 499-515.

Williams L. III, Rodriguez-Saona C., Paré P.W. \& CraftBRANDNER S. 2005: The piercing-sucking herbivores Lygus hesperus and Nezara viridula induce volatile emissions in plants. Arch. Insect Biochem. Physiol. 58: 84-96.

WINTER T.R \& RostÁs M. 2008: Ambient ultraviolet radiation induces protective responses in soybean but does not attenuate indirect defense. Environ. Pollut. 155: 290-297.

ZADRA C., Borgogni A. \& MarucchinI C. 2006: Quantification of jasmonic acid by SPME in tomato plants stressed by ozone. J. Agr. Food Chem. 54: 9317-9321.

Received May 29, 2008; revised and accepted August 8, 2008 